\title{
Harnessing International Remittances for Financial Development: The Role of Monetery Policy
}

\author{
Haruna Issahaku \\ Department of Economics and Entrepreneurship Development, Faculty of \\ Integrated Development Studies, University for Development Studies, Ghana. \\ Email: iharuna@uds.edu.gh \\ DOI//http://dx.doi.org/10.4314/gjds.v16i2.6
}

\begin{abstract}
This study investigates how remittances and monetary policy independently and interactively shape the financial system of developing countries. It employs single equation instrumental variable based estimation procedures to test the hypothesis that, to boost financial development, remittances require a complementary domestic monetary policy framework which ensures price stability while limiting price distortions. The results show that remittances stimulate financial development only in countries with a favourable monetary environment. Building on these results and employing various indicators of financial development, the results suggest that remittances rise to cushion migrant households from the repercussions of poor financial intermediation, weak institutions and unfavourable business environment in the home country. By extension, the findings are germane to monetary and financial policy in developing countries.
\end{abstract}

Keywords: Remittances, Monetary Policy, Financial Development, Developing Country, Financial Development Index

\section{INTRODUCTION}

The empirical work on the finance-growth nexus has now almost unequivocally pronounced finance as imperative for long term growth (Hsueh, $\mathrm{Hu} \& \mathrm{Tu}, 2013$; Jedidia, Boujelbène \& Helali, 2014; Komal \& Abbas, 2015; Levine, 2005). The focus of the literature has now moved towards finding answers as to why some economies have better financial systems than others (Baltagi, Demetriades \& Law, 2009). In this regard, the objective of this paper is to explore whether remittances, the monetary framework and their interactions can deliver improvements in financial development to the developing world, where such improvements are needed most. Figure 1 shows the performance of developing countries (DCs) in selected financial development indicators relative to other parts of the globe. On all the indicators 
(with the exception of market capitalisation excluding top 10 companies and stock price volatility), DCs perform below the global average, and even further below their developed counterparts.

For instance, credit provided by deposit money banks to the private sector as a percent of Gross Domestic Product (GDP) is 51.2 for World, as high as 96.1 for the developed world, but a meagre 35.8 for DCs - a symptom of poor financial deepening in DCs. Similarly, in terms of stock market capitalisation and outstanding domestic private debt securities as a percentage of GDP, the global average is 61.5, compared to 92.4 for developed countries, and a trifling 39.1 for DCs. These poor financial systems in DCs have telling consequences. A dysfunctional financial system obstructs growth, limits economic openings, breads economic instability (Cihak, Demirgüç-Kunt, Feyen \& Levine, 2012), wastes resources, and hinders innovation.

Figure 1: Indicators of financial development (2011-2013): Developed vs developing countries

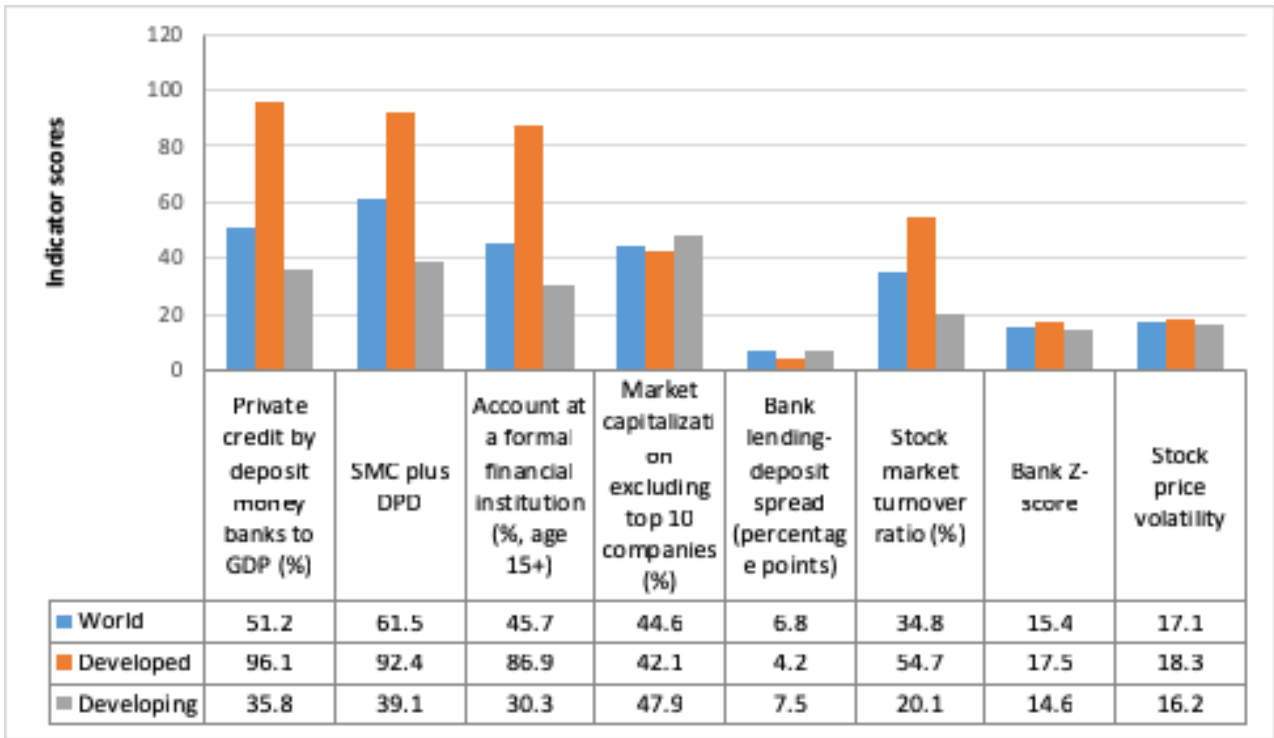

Source: Global financial development database 2011-2013

Note: The comparison in the degree of financial development is done in respect of private credit provided by banks, stock market capitalisation plus outstanding domestic private debt securities to GDP (shortened as SMC plus DPD), number of people with account at a formal financial institution, stock market capitalisation excluding top 10 companies, bank lending deposit spread, stock market turnover ratio, bank z-score and stock price volatility.

Consequently, this paper empirically investigates the individual as well as the interactive effects of remittances and monetary policy on financial development by using a unique dataset which covers 30 DCs. Specifically, the main hypothesis 
tested is that for remittances to exert a positive impact on financial development, a conducive monetary policy environment which ensures price stability while curtailing price distortions is a sine quo non. This means, a blanket policy to attract remittances would yield no real benefit to the domestic financial system unless it is anchored on a sound monetary framework. The hypothesis is grounded on the premise that, a good monetary environment ensures price stability and reduces price distortions which in turn creates an atmosphere that stimulates lending, entrepreneurship, innovation, investment in financial instruments, access to finance, risk mitigation and general economic activity. Under this environment, DCs can hope to get the best out of remittances to boost their financial systems.

Indeed, there is as yet no study that tests this hypothesis. However, there are studies that examine the impact of remittances on financial development (see Issahaku, Abor \& Harvey 2017; Aggarwal, Demirgüç-Kunt \& Pería, 2011; Billmeier \& Massa, 2009; Chowdhury, 2011; Demirgüç-Kunt, Córdova, Pería \& Woodruff, 2011; Gupta, Pattillo \& Wagh, 2009); and studies that investigate the impact of monetary policy on financial development (Bernanke \& Kuttner, 2005; De Graeve, Kick \& Koetter, 2008; Elbourne \& de Haan, 2006; Li, İşcan \& Xu, 2010).

The contribution of this paper is threefold: first, to the best of the author's knowledge, this is the first attempt at examining the interactive effect of remittances and monetary policy on financial development. Previous studies have often examined the interactive effect of remittances and resource endowment on financial development (e.g. Billmeier \& Massa, 2009) and the interactive effect of bank ownership and remittances on financial development (e.g. Cooray, 2012). Second, unlike the extant literature, this study simultaneously investigates the impact each of monetary policy and remittances on financial development while controlling for the other. From an econometric perspective, this helps to avoid possible omitted variable bias and endogeneity. From a policy standpoint, it is important to identify the various factors that affect financial development so that appropriate measures will be put in place to harness these factors.

The third contribution this paper makes to the literature is that, unlike previous literature, it examines the impact of monetary policy and remittances on seven different aspects of financial development namely bank financial intermediation, nonbank financial intermediation, financial markets, financial stability, financial access, business environment and institutional framework. This gives policy makers and market watchers an expanded view of the impact of monetary policy and remittances to enable them make informed decisions. 
From the baseline results, remittance has a negative relation with financial development while monetary effectiveness promotes financial development. Results from advanced estimations point to the fact that a favourable monetary environment is necessary for transforming any negative effect remittances may have on the financial system into a positive one. These findings are robust to different estimation techniques.

The remainder of the paper is organised as follows. Literature review is presented in the next section. The next section after the literature review discusses a research framework on the remittance-monetary policy-financial development nexus. After the research framework, the empirical strategy is discussed. The penultimate section presents results and analytical exposition. The final section contains conclusion and policy implications.

\section{RELATED LITERATURE}

Giuliano and Ruiz-Arranz (2009) argue that the impact of remittances on finance is a priori uncertain. In agreement, Brown et al. (2013) state that remittances can have both positive and negative impacts on financial development but as to which of these effects dominates becomes an empirical question. In this regard, the empirical literature has produced some mixed results.

Billmeier and Massa (2009) observe that remittances foster stock market development mainly in countries that are poorly endowed with hydrocarbon resources. However, in oil rich countries, stock market capitalisation is essentially determined by the price of oil. This result may be due to the fact that in oil rich countries the amount of remittances received may be insignificant relative to the amount of revenue generated from oil. In a study of 44 Sub-Saharan African (SSA) countries from 1975-2004, Gupta et al. (2009) find that remittances promote financial development and reduce poverty. In a related work, Demirgüç-Kunt et al. (2011) find that remittances are associated with increased bank outreach, deposits and account ownership in Mexico. A similar conclusion is reached by Chowdhury (2011) in Bangladesh.

Ezeoha (2013) disputes the claim that local financial market conditions do not affect remittance inflows. In a panel study involving 32 SSA countries, the author shows that substandard financial and physical infrastructure obstruct the flow of remittances while good financial and physical infrastructure facilitate remittance inflows. Consequently, emerging economies are found to be able to attract more remittances than their developing counterparts due to the infrastructure advantage. 
The fact that resource flows can bring in their wake deleterious effects is quite well documented in the literature on the resource curse phenomenon. Indeed, evidence of Dutch disease effect of remittances has been discovered by Acosta, Lartey and Mandelman (2009). According to Acosta et al. (2009) irrespective of the motive for remitting, remittances reduce labour supply while increasing the consumption of non-tradable goods. According to the authors, the increased demand for nontradables leads to an increase in non-tradable goods prices and consequently a movement of labour away from the tradable sector culminating in the Dutch disease effect.

Abdih et al. (2012) investigate the impact of remittances on the quality of governance and institutions in a cross-sectional study of over 100 countries. They find that higher remittance receipts are associated with a worsening of governance indicators such as control of corruption, government effectiveness and rule of law. Thus, remittances provide an incentive for government to appropriate resources for its own use. Via this channel, remittances can weaken the incentive to invest in infrastructure including financial infrastructure and by so doing lower financial development. Also, reduced investments and misallocation of resources arising from the Dutch disease effect can hinder financial development.

Perhaps, the clearest evidence yet of a negative impact of remittances on financial development is one provided by Brown et al. (2013) from both micro and macro data. The macro econometric analysis shows that, remittances reduce financial development. According to the authors, by causing recipient households to bypass the formal financial system for funds by providing alternative funding for investment or consumption, remittances reduce the demand for bank credit and for that matter lower financial development. Also, if recipient households have alternative investment opportunities or lack confidence in the financial system, they will not be motivated to deposit with financial institutions leading to a reduction in the equilibrium quantity of loanable funds. Furthermore, loss of confidence in local financial markets may lower the demand of remittance receiving households for financial instruments which consequently might affect the progress of financial markets. In the micro econometric study, Brown et al. (2013) dispelled the notion that remittance recipients are more likely to be financially literate. They argue that remittances do not increase the probability of a household opening a bank account but rather recipient households tend to favour informal channels due to tedious paper work, high cost and bureaucratic tendencies associated with dealing with banks.

Turning to the link between finance and macroeconomic policy, monetary policy can affect financial sector stability (De Graeve, Kick \& Koetter, 2008), the 
profitability of banks (Cadet, 2009), the return on financial assets (Bernanke \& Kuttner, 2005; Gupta, Jurgilas \& Kabundi, 2010; Gupta et al., 2009), stock prices (Li, İşcan \& Xu, 2010) and financial structure (Elbourne \& de Haan, 2006). On the flip side, finance can influence the efficiency of monetary policy (Krause \& Rioja, 2006). Further, remittances can affect interest rates (Mandelman, 2013; Vacaflores, 2012), inflation (Termos, Naufal \& Genc, 2013) and exchange rate (Stratan \& Chistruga, 2012). Some authors have even suggested that remittances can serve as a substitute for monetary policy in a trilemma framework (Singer, 2010; Termos et al., 2013). At the same time, interest rate differentials can affect remittance inflows (El-Sakka \& McNabb, 1999). This implies that remittances, monetary policy and financial development should be treated as endogenous in a system of equations.

Unlike the above literature, this paper seeks to show that though remittance has mixed effects on finance, the positive effect manifests in countries with a conducive monetary policy environment.

\section{RESEARCH FRAMEWORK}

Figure 2 presents the theoretical framework which shows how international remittances affect domestic financial development with the facilitation of monetary policy. When international remittances flow into the domestic economy they are utilised by households as a source of capital for investment or as income to meet households' needs of food, clothing, shelter, security and leisure. Utilising remittances in this manner may affect financial development positively. This is because, when remittances serve as an alternative source of credit and not a complementary source, it may reduce the demand for bank credit and for that matter lower financial development (Brown et al., 2013).

However, when remittances flow into an economic environment where monetary conditions are good, that is, monetary policy is effective and conducive for investment, remittance recipients will be willing to invest in financial instruments and not to withdraw all remittance proceeds, but be willing to deposit more into the formal banking system. This is due to the high confidence in the financial system brought about by a favourable monetary environment. Consequently, this will increase the amount of loanable funds in the banking system and also provide more funds for investors. With the monetary environment being business friendly, banks will be willing to loan out more funds instead of chasing Treasury bill related profits. A conducive monetary environment will moderate risk in the economy and for that matter reduce the risk of loan defaults. A good monetary environment will also increase the demand of households, including remittance receiving households, 
for various financial instruments such as stocks, bonds, treasury bills, bank loans, microcredit, and insurance among others. All of these will lead to a high level of financial development.

Figure 2: Framework of effect of remittances on finance through monetary policy

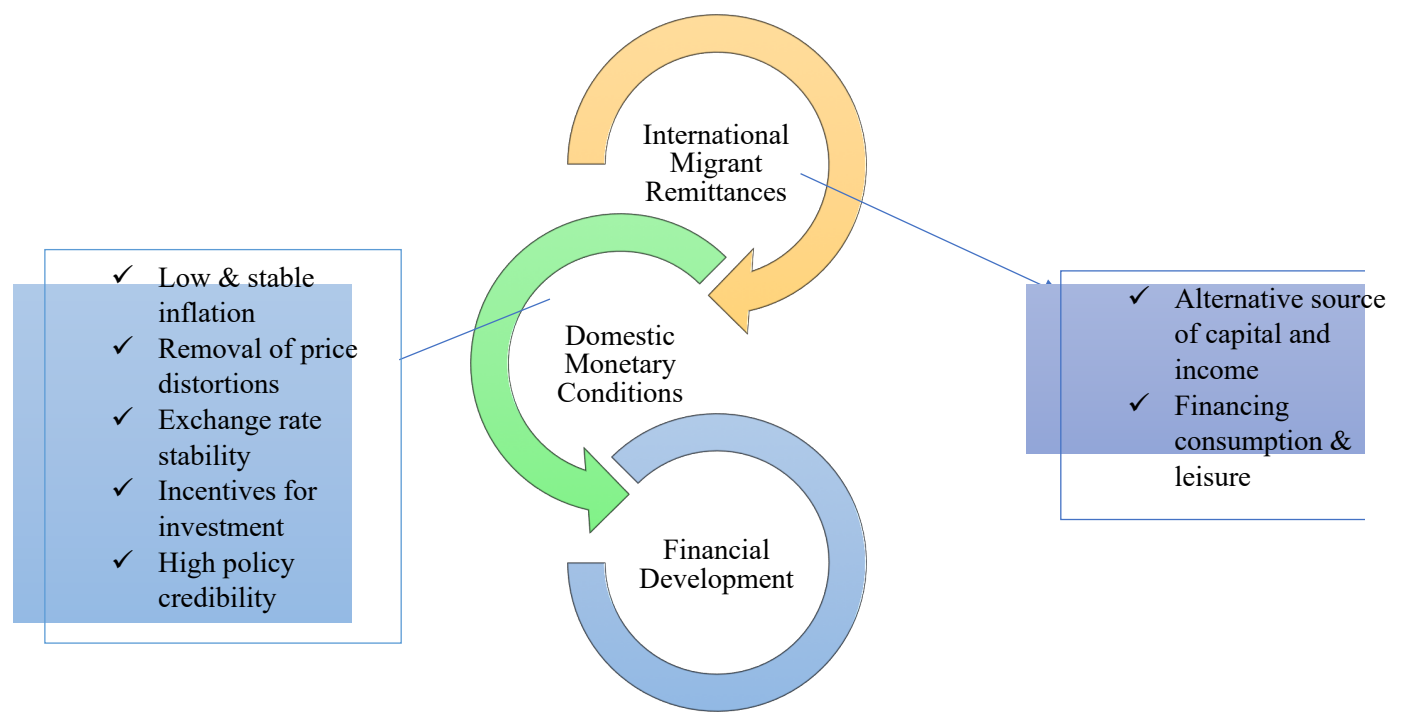

Source: Authors' own construction

A favourable monetary environment is able to make remittances effective by (a) ensuring a low and stable inflation, (b) removing or reducing price distortions, (c) ensuring exchange rate stability, (d) reducing risk and providing incentives for investments and (e) increasing business confidence as a result of high level of policy credibility. Consequently, with a favourable monetary environment, remittances can positively affect financial development, otherwise remittances will go to cushion households by financing consumption and leisure.

\section{EMPIRICAL STRATEGY}

The empirical strategy involves the use of instrumental variable based methods to establish the relationships among remittances, monetary policy and financial development measures. 


\section{The Model}

Financial development is modelled as a function of monetary policy, remittances and control variables as follows:

$$
F D_{-} I N D E X_{i t}=\tau_{1} M O N_{-} F R E_{i t-1}+\tau_{2} R E M I T_{i t}+\tau_{3} I N T E R A C T_{i t}+B X_{i t}+e_{i t}
$$

where FD_INDEX is the financial development index, MON_FRE is monetary policy, which is proxied by monetary freedom, REMIT is migrant remittances as a ratio of GDP, $i$ is country dimension while $t$ is time dimension, $e$ is the composite error term. $X$ is a vector of control variables such as trade openness, financial openness, property rights, gross savings, interest rates, and labour freedom. INTERACT is a multiplicative interactive term between remittances and monetary policy. and $B$ are coefficients. The main problem in estimating equation 1 is how to deal with the endogeneity of financial development, remittances and monetary policy. To deal with this problem, a number of IV based estimation methods have been applied. The first method applied is heteroscedasticity and autocorrelation consistent instrumental variable (HAC-IV) estimation which produces results which are efficient even in the presence of heteroscedasticity and autocorrelation.

The second method applied is the efficient GMM estimator which produces unbiased estimates when the assumption of independently and identically distributed (i.i.d) errors is relaxed or violated. Thus, the GMM performs better than the traditional IV when the errors are non i.i.d. The third method applied is the limited information maximum likelihood (LIML) procedure which estimates the single equation model via the method of maximum likelihood. According to Davidson and MacKinnon (1993) LIML is preferred to other single equation methods when the sample size is small to moderate and when there are many over identifying restrictions. Under the assumption of normality, LIML is the most efficient among all single equation estimators (Greene, 2003). The fourth and last method applied is the continuously updated GMM (CUE-GMM). It is a GMM generalisation of the LIML to cater for arbitrary heteroscedasticity and autocorrelation in the errors. Hansen J statistic is used to test the validity of instruments. The null hypothesis is that the instruments are jointly valid and that the excluded instruments have been correctly excluded.

Good instruments are hard to come by. In the literature, either internal instruments or external instruments are employed. Following Issahaku et al. (2017), this study employs the lags of the endogenous regressors (monetary policy and remittances) as instruments. The instrument tests conducted show that the use of the lags as instruments in this study is valid. The equations are exactly identified and for that matter there is no need to perform over identifying restrictions' tests. 


\section{Data and Description of Variables}

The main dependent variable - financial development and its disaggregated components are hand-picked from the annual reports of the WEF's Financial Development Reports published from 2008-2012. The data ends at 2012 because the WEF has stopped producing the reports since then.

\section{Measuring Financial Development}

Following discontent with the use of single indicator measures of financial development, the WEF, developed an all-encompassing measure of financial development. The WEF's measure of financial development, which is denoted here as FD_INDEX, is anchored on seven pillars, each with 2-4 sub pillars. These seven pillars are grouped further into three major indicators: Factors, Policies and Institutions; Financial Intermediation; and Financial Access. Details of the dimensions of the FD_INDEX are presented in Table 1. The FD_INDEX has been chosen for three main reasons. First, the FD_INDEX covers almost all segments of financial markets, institutions and systems, thereby allowing for a holistic consideration of the impact of economic policy and remittances on finance. Second, not only is the index broadbased, in terms of quality, it recognises that financial development goes beyond financial deepening. In this regard, the measure captures the depth, breadth, structure, stability and efficiency of financial markets, institutions and systems. Lastly, because of its comprehensiveness and high quality, policy prescriptions based on the FD_INDEX will be more reliable than those proceeding from single variable measures and skewed indices of financial development.

The FD-INDEX is used by the WEF to rank countries in terms of their degree of financial development. It takes values between 1 and 7 with a score of 1 indicating the worst and 7 best financial development. Table 2 reports the overall scores of financial development in 2012 for 62 countries across the globe along with the 2011 ranking and the change in scores. No developing country was ranked among the top 15 countries in both 2011 and 2012. The highest ranked developing country in 2012 was Malaysia, which was ranked 16 with an FD_INDEX of 4.24. There is a clear clustering of developing countries at the tail of the table. This means that high (low) financial development is highly correlated with high (low) economic development. Hong Kong SAR is the most advanced in financial development while Venezuela has the worse financial development scores. Majority of the countries improved their scores over the previous year implying that the efforts by developing countries to improve their financial architecture is yielding dividends - albeit slowly. The countries in bold fonts are the 30 DCs included in the study (Table 2). DCs excluded from the study do not have sufficient data on FD_INDEX. 


\section{Measurement of Monetary Policy Effectiveness, Remittances and Controls}

The main regressors in this study are monetary policy and remittances. The main measure of monetary policy effectiveness in this paper is the Heritage Foundation's monetary freedom index (MON_FRE) captured in the annual Index of Economic Freedom reports. MON_FRE is computed as a weighted average of price stability and the degree of financial controls. The values of MON_FRE range from o to 100, with 100 indicating the best monetary policy outcomes. This measure is chosen because the overarching goal of monetary policy is to ensure that prices are stable. Secondly, both inflation and price controls interfere with economic and market activity. Lastly, since larger values of MON_FRE portray better monetary policy efficiency, the interpretation of coefficients is easier. For instance, if there is a synergetic benefit from monetary policy and remittances, then the coefficient of the interaction (INTERACT) between remittances and MON_FRE must be positive.

This study employs Money Market Interest Rates (MMIR) as an additional monetary policy measure. Increases in interest rate decrease financial stability (Cadet, 2009; De Graeve et al., 2008), so a negative coefficient is envisaged for the MMIR. The short term interest rate has been used by previous studies as a proxy for monetary policy (Amidu \& Wolfe, 2013).

Remittance is measured as the proportion of total international migrant remittances in GDP. The expected sign for the remittance coefficient is uncertain since there is no agreement in the literature on the effect of remittances on finance. Variables such as property rights (PTY_RIGHTS), financial openness (FINC_OPEN), trade openness (TRADE_OPEN) which are often included in classical studies of financial development determinants have been included as controls. The thoroughly cited seminal work of La Porta, Lopez-de-Silane, Shleifer and Vishny (1996), 'Law and finance' extols the role of legal systems in promoting financial development. Thus, the proxy for legal quality (PTY-RIGHTS) is expected to have a positive coefficient. Several studies (e.g. Ginebri, Petrioli \& Sabani, 2001; Rajan \& Zingales, 2003) show that by increasing the reward for financing entrepreneurs and promoting capital market activity, trade and financial openness improve financial systems. Savings (GS), and labour freedom (LAB_FRE) are included as additional controls. The measurement of each variable is described in Table A.1 in the appendix. 
Table 1: Components of financial development (FD_INDEX)

\begin{tabular}{|c|c|c|c|c|c|c|c|}
\hline \multirow{2}{*}{$\begin{array}{l}\text { Broad Class } \\
\text { Main Pillars }\end{array}$} & \multicolumn{2}{|c|}{$\begin{array}{l}\text { Institutions, Factors and } \\
\text { Policies }\end{array}$} & \multicolumn{3}{|c|}{ Financial Intermediation } & \multicolumn{2}{|c|}{ Financial Access } \\
\hline & $\begin{array}{l}\text { Pillar 1: } \\
\text { Institutional } \\
\text { Environment }\end{array}$ & $\begin{array}{l}\text { Pillar 2: } \\
\text { Business } \\
\text { Environment }\end{array}$ & $\begin{array}{l}\text { Pillar 3: } \\
\text { Financial } \\
\text { Stability }\end{array}$ & $\begin{array}{l}\text { Pillar 4: } \\
\text { Banking } \\
\text { Financial } \\
\text { Services }\end{array}$ & $\begin{array}{l}\text { Pillar 5: Non- } \\
\text { Banking } \\
\text { Financial } \\
\text { Services }\end{array}$ & $\begin{array}{l}\text { Pillar 6: } \\
\text { Financial } \\
\text { Markets }\end{array}$ & $\begin{array}{l}\text { Pillar 7: } \\
\text { Financial } \\
\text { Access }\end{array}$ \\
\hline \multirow[t]{4}{*}{ Sub-Pillars } & $\begin{array}{l}\text { Financial } \\
\text { sector } \\
\text { liberalization }\end{array}$ & Human capital & $\begin{array}{l}\text { Currency } \\
\text { stability }\end{array}$ & Size index & IPO activity & $\begin{array}{l}\text { Foreign } \\
\text { exchange } \\
\text { markets }\end{array}$ & $\begin{array}{l}\text { Commercial } \\
\text { access }\end{array}$ \\
\hline & $\begin{array}{l}\text { Corporate } \\
\text { governance }\end{array}$ & Taxes & $\begin{array}{l}\text { Banking } \\
\text { sector } \\
\text { stability }\end{array}$ & $\begin{array}{l}\text { Efficiency } \\
\text { index }\end{array}$ & M\&A activity & $\begin{array}{l}\text { Derivative } \\
\text { markets }\end{array}$ & $\begin{array}{l}\text { Retail } \\
\text { access }\end{array}$ \\
\hline & $\begin{array}{l}\text { Legal \& } \\
\text { regulatory } \\
\text { issues }\end{array}$ & Infrastructure & $\begin{array}{l}\text { Risk of } \\
\text { sovereign } \\
\text { debt crises }\end{array}$ & $\begin{array}{l}\text { Financial } \\
\text { information } \\
\text { disclosure }\end{array}$ & Securitization & $\begin{array}{l}\text { Equity market } \\
\text { development }\end{array}$ & \\
\hline & $\begin{array}{l}\text { Contract } \\
\text { enforcement }\end{array}$ & $\begin{array}{l}\text { Cost of doing } \\
\text { business }\end{array}$ & & & & $\begin{array}{l}\text { Bond market } \\
\text { development }\end{array}$ & \\
\hline
\end{tabular}

Source: WEF's 2013 financial development report

Table 2: A comparison of financial development (FD_INDEX) in developed and developing countries

\begin{tabular}{|l|l|l|l|l|l|}
\hline Country & $\begin{array}{l}\mathbf{2 0 1 2} \\
\text { Rank }\end{array}$ & $\begin{array}{l}\mathbf{2 0 1 1} \\
\text { Rank }\end{array}$ & $\begin{array}{l}\mathbf{2 0 1 2} \text { Score } \\
(\mathbf{1 - 7})\end{array}$ & $\begin{array}{l}\text { Change in } \\
\text { Score }\end{array}$ & $\begin{array}{l}\text { Country } \\
\text { Status }\end{array}$ \\
\hline Hong Kong SAR & 1 & 1 & 5.31 & 0.15 & Developed \\
\hline United States & 2 & 2 & 5.27 & 0.12 & Developed \\
\hline United Kingdom & 3 & 3 & 5.21 & 0.21 & Developed \\
\hline Singapore & 4 & 4 & 5.10 & 0.14 & Developed \\
\hline Australia & 5 & 5 & 5.01 & 0.08 & Developed \\
\hline Canada & 6 & 6 & 5.00 & 0.14 & Developed \\
\hline Japan & 7 & 8 & 4.90 & 0.19 & Developed \\
\hline Switzerland & 8 & 9 & 4.78 & 0.15 & Developed \\
\hline Netherlands & 9 & 7 & 4.73 & 0.02 & Developed \\
\hline Sweden & 10 & 11 & 4.71 & 0.20 & Developed \\
\hline Germany & 11 & 14 & 4.61 & 0.28 & Developed \\
\hline Denmark & 12 & 15 & 4.53 & 0.22 & Developed \\
\hline Norway & 13 & 10 & 4.52 & 0.01 & Developed \\
\hline France & 14 & 12 & 4.43 & -0.01 & Developed \\
\hline Korea, Rep. & 15 & 18 & 4.42 & 0.29 & Developed \\
\hline Belgium & 16 & 13 & 4.30 & -0.08 & Developed \\
\hline Finland & 17 & 21 & 4.24 & 0.13 & Developed \\
\hline
\end{tabular}


Ghana Journal of Development Studies, Vol. 16 (2)

Table 2 Con't.

\begin{tabular}{|c|c|c|c|c|c|}
\hline Country & $\begin{array}{l}2012 \\
\text { Rank }\end{array}$ & $\begin{array}{l}2011 \\
\text { Rank }\end{array}$ & $\begin{array}{l}2012 \text { Score } \\
(1-7)\end{array}$ & $\begin{array}{l}\text { Change in } \\
\text { Score }\end{array}$ & $\begin{array}{l}\text { Country } \\
\text { Status }\end{array}$ \\
\hline Malaysia & 18 & 16 & 4.24 & -0.01 & Developing \\
\hline Spain & 19 & 17 & 4.22 & -0.02 & Developed \\
\hline Ireland & 20 & 22 & 4.14 & 0.04 & Developed \\
\hline Kuwait & 21 & 28 & 4.03 & 0.31 & Developing \\
\hline Austria & 22 & 20 & 4.01 & -0.10 & Developed \\
\hline China & 23 & 19 & 4.00 & -0.12 & Developing \\
\hline Israel & 24 & 26 & 3.94 & 0.07 & Developed \\
\hline Bahrain & 25 & 24 & 3.93 & 0.04 & Developed \\
\hline United Arab Emirates & 26 & 25 & 3.84 & -0.05 & Developed \\
\hline Portugal & 27 & $\mathrm{n} / \mathrm{a}$ & 3.76 & $\mathrm{n} / \mathrm{a}$ & Developed \\
\hline South Africa & 28 & 29 & $3 \cdot 71$ & 0.08 & Developing \\
\hline Chile & 29 & 31 & 3.69 & 0.08 & Developing \\
\hline Italy & 30 & 27 & 3.69 & -0.16 & Developed \\
\hline Saudi Arabia & 31 & 23 & 3.68 & -0.22 & Developed \\
\hline Brazil & 32 & 30 & 3.61 & 0.00 & Developing \\
\hline Jordan & 33 & 32 & $3 \cdot 56$ & 0.08 & Developing \\
\hline Thailand & 34 & 35 & $3 \cdot 55$ & 0.22 & Developing \\
\hline Czech Republic & 35 & 34 & 3.49 & 0.08 & Developed \\
\hline Panama & 36 & 37 & 3.42 & 0.19 & Developing \\
\hline Poland & 37 & 33 & $3 \cdot 41$ & -0.05 & Developing \\
\hline Slovak Republic & 38 & 38 & $3 \cdot 34$ & 0.12 & Developed \\
\hline Russian Federation & 39 & 39 & $3 \cdot 30$ & 0.12 & Developing \\
\hline India & 40 & 36 & 3.29 & 0.00 & Developing \\
\hline Peru & 41 & 40 & 3.28 & 0.12 & Developing \\
\hline Turkey & 42 & 43 & 3.27 & 0.13 & Developing \\
\hline Mexico & 43 & 41 & 3.25 & 0.09 & Developing \\
\hline Hungary & 44 & 47 & 3.16 & 0.13 & Developing \\
\hline Morocco & 45 & 42 & 3.15 & 0.00 & Developing \\
\hline Colombia & 46 & 45 & 3.15 & 0.06 & Developing \\
\hline Kazakhstan & 47 & 46 & 3.13 & 0.06 & Developing \\
\hline Greece & 48 & $\mathrm{n} / \mathrm{a}$ & 3.12 & $\mathrm{n} / \mathrm{a}$ & Developed \\
\hline Philippines & 49 & 44 & 3.12 & 0.00 & Developing \\
\hline Indonesia & 50 & 51 & 2.95 & 0.03 & Developing \\
\hline
\end{tabular}


Table 2 Con't.

\begin{tabular}{|l|l|l|l|l|l|}
\hline Country & $\begin{array}{l}2012 \\
\text { Rank }\end{array}$ & $\begin{array}{l}2011 \\
\text { Rank }\end{array}$ & $\begin{array}{l}2012 \text { Score } \\
(1-7)\end{array}$ & $\begin{array}{l}\text { Change in } \\
\text { Score }\end{array}$ & $\begin{array}{l}\text { Country } \\
\text { Status }\end{array}$ \\
\hline Romania & 51 & 52 & 2.93 & 0.08 & Developing \\
\hline Vietnam & 52 & 50 & 2.92 & -0.05 & Developing \\
\hline Egypt & 53 & 49 & 2.78 & -0.22 & Developing \\
\hline Kenya & 54 & $\mathbf{n} / \mathbf{a}$ & $\mathbf{2 . 7 5}$ & $\mathbf{n} / \mathbf{a}$ & Developing \\
\hline Argentina & 55 & 53 & 2.68 & -0.01 & Developing \\
\hline Ghana & 56 & 58 & 2.67 & $\mathbf{0 . 1 2}$ & Developing \\
\hline Bangladesh & 57 & 56 & 2.62 & $\mathbf{0 . 0 4}$ & Developing \\
\hline Pakistan & 58 & 55 & 2.61 & 0.03 & Developing \\
\hline Ukraine & 59 & 54 & 2.56 & -0.06 & Developing \\
\hline Tanzania & 60 & 57 & 2.55 & $\mathbf{0 . 0 0}$ & Developing \\
\hline Nigeria & 61 & 60 & 2.46 & $\mathbf{0 . 0 3}$ & Developing \\
\hline Venezuela & 62 & 59 & 2.37 & -0.07 & Developing \\
\hline
\end{tabular}

Source: WEF's 2013 financial development report.

Note: The list of 30 developing countries included in the study is in bold type.

\section{ANALYSIS AND DISCUSSION OF RESULTS}

The baseline results are shown in Table 3. Starting with the model diagnostics, the F-statistics show that, for all the models, the explanatory variables jointly and significantly determine the degree of financial market development. The Hansen J statistic which tests instrument validity shows that, for all the models, all the instruments are jointly valid. These two tests show that the models are valid. The measure of monetary policy effectiveness, monetary freedom (MON_FRE) shows a positive and significant effect on finance in all models. When efficient monetary conditions prevail, prices and interest rates are low and stable which in turn spur the demand for financial products and services. Also, a stable macroeconomic environment helps financial institutions to plan more effectively and for that matter improve their bottom line. All of these lead to financial development.

Remittance shows a negative and significant relationship with financial development in all the models. The negative association between remittances and finance is justified on several grounds. The first interpretation is that remittances ameliorate credit constraints in countries with weak financial systems. In creditconstrained economies, remittance receiving households may not rely on financial institutions for credit but instead may rely on their family members overseas. The alleviation of credit constraints by remittances may in fact reduce the demand 
for formal credit and for that matter lower the amount of credit given out by banks. Thus, remittances act as substitutes for financial development especially in countries with low financial development by serving as alternative means of obtaining funding for investment, consumption and other purposes. Another plausible explanation is that remittances may be immediately consumed and for that matter will not increase the amount of loanable funds in the banking system. Thirdly, even when remittance recipients deposit remittances cash in banks thereby increasing the volume of loanable funds, banks may be unwilling to lend out more money due to unfavourable macroeconomic conditions (particularly, monetary policy). In an unstable macroeconomic environment, banks may prefer to hold more liquid assets to giving out loans.

This is clear from the positive coefficient of MON_FRE. When monetary policy is conducted such that price stability is attained and price controls are removed or minimised, market distortions are minimal, firms can plan with more certainty, price allocation becomes more efficient, and financial institutions and systems flourish. These possible explanations for a negative effect of remittances on finance agree with Aggarwal et al. (2011), Brown et al. (2013) and Issahaku et al. (2017). Among the control variables, only financial openness is significant with a positive coefficient as expected. 


\section{Table 3: Baseline results}

Financial development (FD_INDEX) is the dependent variable in all models. ${ }^{*},{ }^{* *},{ }^{* * *}$ respectively denote significance at $10 \%, 5 \%, 1 \%$ level of significance. The measurement of each variable is described in Table A.1 in the appendix.

\begin{tabular}{|c|c|c|c|c|}
\hline & (1) & (2) & (3) & (4) \\
\hline VARIABLES & HAC-IV & CUE-GMM & GMM & LIML \\
\hline \multirow[t]{2}{*}{ MON_FRE } & $1.730^{*}$ & $1.852^{* *}$ & $1.829^{* *}$ & $1.929^{*}$ \\
\hline & (o.89o) & $(0.916)$ & $(0.882)$ & $(0.995)$ \\
\hline \multirow[t]{2}{*}{ REMIT } & $-0.102^{*}$ & $-0.105^{*}$ & $-0.106^{*}$ & $-0.117^{*}$ \\
\hline & $(0.0612)$ & $(0.0627)$ & $(0.0608)$ & (0.0686) \\
\hline \multirow[t]{2}{*}{ TRADE_OPEN } & 0.00282 & -0.000707 & 0.00294 & -0.00253 \\
\hline & $(0.0397)$ & $(0.0408)$ & (0.0395) & (0.0437) \\
\hline \multirow[t]{2}{*}{ PTY_RIGHTS } & -0.00348 & -0.00408 & -0.00401 & -0.00442 \\
\hline & $(0.00442)$ & $(0.00450)$ & $(0.00435)$ & $(0.00496)$ \\
\hline \multirow[t]{2}{*}{ GS } & -0.0667 & -0.0728 & -0.0768 & -0.0780 \\
\hline & (0.0691) & $(0.0697)$ & $(0.0677)$ & (o.0759) \\
\hline \multirow[t]{2}{*}{ FINC_OPEN } & $0.0986^{* * *}$ & $0.0992^{* * *}$ & $0.102^{* * *}$ & $0.106^{* * *}$ \\
\hline & (0.0371) & (0.0371) & $(0.0361)$ & (0.0410) \\
\hline \multirow[t]{2}{*}{ MMIR } & -0.00888 & -0.00869 & -0.00895 & -0.00889 \\
\hline & $(0.00556)$ & $(0.00573)$ & $(0.00555)$ & (0.00613) \\
\hline \multirow[t]{2}{*}{ LAB_FRE } & -0.000203 & -0.000312 & -0.000453 & -0.000143 \\
\hline & (0.00133) & (0.00128) & (0.00125) & (0.00147) \\
\hline \multirow[t]{2}{*}{ Constant } & $-5.863^{* *}$ & $-6.278^{* *}$ & $-6.213^{* *}$ & $-6.479^{*}$ \\
\hline & $(2.976)$ & (3.059) & $(2.942)$ & $(3.320)$ \\
\hline \multicolumn{5}{|l|}{ Diagnostics } \\
\hline Observations & 137 & 137 & 137 & 137 \\
\hline F-statistics & $4.48^{* * *}$ & $4.48^{* * *}$ & $4.88^{* * *}$ & $4.09^{* * *}$ \\
\hline Hansen J & 0.844 & 0.844 & 0.848 & 0.815 \\
\hline$P$ value & 0.6557 & 0.6557 & 0.6544 & 0.665 \\
\hline
\end{tabular}

Source: Author's analysis

Though Aggarwal et al. (2011) and Brown et al. (2013) recognised that certain factors may affect bank's (un)willingness to make more loans out of remittance deposits they did not explore the issue further. This study argues that one factor that is instrumental for bank lending is the monetary policy environment. If the monetary policy set up is such that it favours investments in liquid assets (e.g. treasury bills), disrupts market pricing, and increases information asymmetries, then, banks 
will be reluctant to grant credit even if they have accumulated large volumes of deposits. The overarching hypothesis tested in this paper is that, for remittances to bring the desired improvements in the financial architecture of recipient countries, a conducive monetary environment is required. This hypothesis is tested by incorporating interaction term in the estimations. Results with the inclusion of the interaction term (INTERACT) between REMIT and MON_FRE are reported in Table 4.

The inclusion of INTERACT does not qualitatively alter the outcomes. It is clear from models (1) to (4) that remittance has a substitutionary (negative) solo influence on finance; monetary effectiveness has a positive solo effect on finance; and the interactive term has a positive effect on finance. These coefficients are statistically significant. Though the coefficients of the interactive term look small, they are not negligible. It must be borne in mind that the measure of financial development has been compressed to fall within the range 1 to 7 . Thus, the coefficient of the interaction term which is about 0.0004 has some economic significance. The other implication is that, once it is showing a positive sign, it means that further improvements in monetary policy efficiency will boost the magnitude of the coefficients beyond what it is currently.

Thus, a favourable monetary regime can overturn any negative effect remittances may have on financial development, delivering a positive benefit to overall financial development. These findings suggest that in order to help promote overall financial development, remittances require a conducive monetary policy environment. An attempt by a country to attract more capital flows in the form of remittances, without complementing those efforts with price stability and a generally 'monetarily free' atmosphere may actually set up remittances as substitutes for financial development.

Next, the study explores whether remittances, monetary policy and their interactions have the same effect on the disaggregated components of financial development. The results are shown in Table 5 with models estimated using instrumental variable estimations with heteroscedasticity and autocorrelation consistent errors (HAC-IV).

The discussion here starts with remittances, monetary conditions and their interactions on the sub-components of financial intermediation namely bank financial services (BANKS), nonbank financial services (NONBANKS), and financial markets (FINC_MKTS). It can be seen from Table 5 that the solo effect of remittances on all the subcomponents of financial intermediation is negative with the coefficients being significant. This buttresses the earlier finding that in countries where financial development is low, remittance inflows increase to alleviate credit 
constraints. Thus, when financial markets and institutions fail in their duties to provide affordable and accessible funds to households, or fail to meet other financial needs of households, remittances provide an 'insurance cover'. A recent study by Bettin, Presbitero and Spatafora (2015) explains how remittances rescue households in their most vulnerable moments. The finding that remittances are negatively associated with financial development indicators is in accord with Brown et al. (2013) and Issahaku et al. (2017).

Table 4: Baseline results augmented by the interaction term

\begin{tabular}{|c|c|c|c|c|}
\hline & (1) & $(2)$ & (3) & (4) \\
\hline VARIABLES & HAC-IV & CUE-GMM & GMM & LIML \\
\hline \multirow[t]{2}{*}{ MON_FRE } & $0.943^{* * *}$ & $0.919^{* *}$ & $0.894^{* *}$ & $1.001^{* *}$ \\
\hline & $(0.314)$ & $(0.378)$ & $(0.382)$ & $(0.404)$ \\
\hline \multirow[t]{2}{*}{ REMIT } & $-0.0777^{* *}$ & $-0.0783^{* * *}$ & $-0.0777^{* * *}$ & $-0.0828^{* * *}$ \\
\hline & $(0.0302)$ & (0.0301) & (0.0301) & $(0.0316)$ \\
\hline \multirow[t]{2}{*}{ INTERACT } & $0.000377^{*}$ & $0.000387^{* *}$ & $0.000388^{* *}$ & $0.000400^{* *}$ \\
\hline & (0.000195) & (0.000170) & (0.000170) & (0.000180) \\
\hline \multirow[t]{2}{*}{ TRADE_OPEN } & -0.00628 & -0.00975 & -0.00852 & -0.00927 \\
\hline & $(0.0341)$ & $(0.0298)$ & (0.0299) & $(0.0308)$ \\
\hline \multirow[t]{2}{*}{ PTY_RIGHTS } & 0.00206 & 0.00212 & 0.00222 & 0.00192 \\
\hline & $(0.00158)$ & (0.00170) & $(0.00172)$ & $(0.00181)$ \\
\hline \multirow[t]{2}{*}{ GS } & 0.0541 & 0.0570 & 0.0565 & 0.0563 \\
\hline & $(0.0416)$ & $(0.0408)$ & $(0.0410)$ & (0.0431) \\
\hline \multirow[t]{2}{*}{ FINC_OPEN } & $0.0994^{* * *}$ & $0.101^{* * *}$ & $0.102^{* * *}$ & $0.103^{* * *}$ \\
\hline & $(0.0318)$ & $(0.0278)$ & $(0.0276)$ & (0.0291) \\
\hline \multirow[t]{2}{*}{ MMIR } & -0.00607 & -0.00597 & -0.00603 & -0.00581 \\
\hline & $(0.00381)$ & (0.00369) & $(0.00372)$ & (0.00388) \\
\hline \multirow[t]{2}{*}{ LAB_FRE } & -0.00122 & -0.00125 & -0.00133 & -0.00126 \\
\hline & $(0.000832)$ & (0.00100) & (0.00100) & (0.00104) \\
\hline \multirow[t]{2}{*}{ Constant } & $-3.639^{* * *}$ & $-3.569^{* * *}$ & $-3.495^{* *}$ & $-3.848^{* * *}$ \\
\hline & $(1.154)$ & $(1.358)$ & $(1.377)$ & $(1.449)$ \\
\hline \multicolumn{5}{|l|}{ Diagnostics } \\
\hline Observations & 137 & 137 & 137 & 137 \\
\hline F-statistic & $9.81^{* * *}$ & 9.19 & $9.12^{* * *}$ & $8.63^{* * *}$ \\
\hline Hansen J & 0.722 & 0.695 & 0.677 & 0.661 \\
\hline$P$ value & 0.6971 & 0.7065 & 0.7128 & 0.7187 \\
\hline
\end{tabular}

Source: Author's analysis

Note: Financial development (FD_INDEX) is the dependent variable in all models. *, **, *** respectively denote significance at 10\%, 5\%, 1\% level of significance. The measurement of each variable is described in Table A.1 in the appendix. 
Table 5: Effect of monetary policy and remittances on measures of financial development

\begin{tabular}{|c|c|c|c|c|c|c|c|}
\hline & (1) & (2) & (3) & (4) & $(5)$ & $(6)$ & (7) \\
\hline VARIABLES & BANKS & NONBANKS & FINC_MKT & ACCESS & INST_ENV & $\begin{array}{l}\text { BUS_- } \\
\text { ENV }\end{array}$ & $\begin{array}{l}\text { FINC_ } \\
\text { STAB }\end{array}$ \\
\hline \multirow[t]{2}{*}{ MON_FRE } & 0.278 & 0.485 & 0.407 & $4.316^{* * *}$ & $3.567^{* * *}$ & $1.187^{* * *}$ & $1.629^{* *}$ \\
\hline & $(0.250)$ & (o.891) & $(0.787)$ & (1.373) & $(0.978)$ & $(0.424)$ & $(0.672)$ \\
\hline \multirow[t]{2}{*}{ REMIT } & $-0.0711^{*}$ & $-0.152^{* * *}$ & $-0.137^{* *}$ & $-0.338^{*}$ & -0.0726 & $-0.0768^{* *}$ & 0.0934 \\
\hline & (0.0389) & (0.0537) & (0.0549) & $(0.173)$ & $(0.0856)$ & (o.0353) & $(0.0578)$ \\
\hline \multirow[t]{2}{*}{ INTERACT } & $0.00058^{* *}$ & $0.00104^{* * *}$ & $0.001^{* * *}$ & $0.00192^{*}$ & -0.000201 & 0.000178 & $-0.0008^{*}$ \\
\hline & (0.000260) & (0.000328) & (0.0003) & (0.00112) & (0.000543) & (0.0002) & $(0.0004)$ \\
\hline \multirow{2}{*}{$\begin{array}{l}\text { TRADE_ } \\
\text { OPEN }\end{array}$} & $0.125^{* * *}$ & $-0.120^{*}$ & -0.0591 & 0.143 & $0.435^{* * *}$ & $0.0869^{* *}$ & -0.0608 \\
\hline & (0.0452) & (0.0629) & (0.066o) & (0.193) & $(0.105)$ & $(0.0386)$ & (0.0653) \\
\hline \multirow[t]{2}{*}{ PTY_RIGHTS } & 0.00377 & 0.00444 & $0.00720^{*}$ & 0.00762 & 0.00773 & 0.000553 & $-0.0065^{*}$ \\
\hline & $(0.00242)$ & (0.00421) & (0.00380) & (0.00860) & $(0.00527)$ & (0.00192) & $(0.00344)$ \\
\hline \multirow[t]{2}{*}{ GS } & 0.0665 & $0.217^{* *}$ & 0.103 & 0.416 & -0.136 & -0.00635 & -0.101 \\
\hline & (0.0620) & (0.0842) & (0.101) & (0.266) & (0.112) & $(0.0452)$ & (0.0941) \\
\hline \multirow[t]{2}{*}{ FINC_OPEN } & $0.111^{* *}$ & $0.303^{* * *}$ & $0.198^{* * *}$ & $0.373^{* *}$ & 0.0928 & $0.0860^{* *}$ & $-0.0857^{*}$ \\
\hline & $(0.0461)$ & (0.0610) & (0.0618) & (0.154) & (0.0732) & (0.0335) & (0.0480) \\
\hline \multirow[t]{2}{*}{ MMIR } & $-0.0172^{* * *}$ & -0.00874 & -0.0122 & 0.0321 & -0.0212 & -0.000178 & $-0.0131^{*}$ \\
\hline & $(0.00636)$ & $(0.00892)$ & (0.0109) & $(0.0272)$ & $(0.0131)$ & (0.00451) & (0.00757) \\
\hline \multirow[t]{2}{*}{ LAB_FRE } & $-0.0037^{* * *}$ & -0.00338 & -0.00296 & -0.00541 & 0.00301 & -0.00131 & 0.00277 \\
\hline & (0.00115) & $(0.00212)$ & $(0.00186)$ & (0.00461) & $(0.00306)$ & (0.0010) & (0.00230) \\
\hline \multirow[t]{2}{*}{ Constant } & -1.733 & $-5.268^{*}$ & -2.986 & $-18.85^{* * *}$ & $-13.79^{* * *}$ & $-4 \cdot 326^{* *}$ & -4.750 \\
\hline & (1.145) & (3.003) & $(2.928)$ & $(5.876)$ & (3.994) & $(1.679)$ & $(2.987)$ \\
\hline \multicolumn{8}{|l|}{ Diagnostics } \\
\hline Observations & 137 & 137 & 137 & 126 & 137 & 132 & 109 \\
\hline R-squared & 0.224 & 0.318 & -0.104 & -0.127 & 0.546 & 0.005 & -0.108 \\
\hline F-statistic & $10.29^{* * *}$ & $11.78^{* * *}$ & $2.94^{* *}$ & $3.45^{* * *}$ & $18.97^{* * *}$ & $14.25^{* * *}$ & $4.97^{* * *}$ \\
\hline Hansen J & 1.065 & 2.189 & 0.763 & 9.051 & 0.655 & 4.133 & 5.973 \\
\hline P value & 0.5870 & 0.3347 & 0.6829 & 0.1071 & 0.7208 & 0.1266 & 0.1129 \\
\hline
\end{tabular}

Source: Author's analysis

The disaggregated measures of financial development are the dependent variables. The models have been estimated using HAC-IV method. ${ }^{*}{ }^{* *},{ }^{* * *}$ respectively denote significance at $10 \%, 5 \%, 1 \%$ level of significance. The measurement of each variable is described in Table A.1 in the appendix.

But, does the finding that remittances are negatively correlated with financial intermediation imply that financial intermediaries do not and cannot benefit from remittances? Once again, the interaction term (INTERACT) provides answers. The coefficient of INTERACT is positive and significant for BANKS (Model 1), NONBANKS (Model 2) and FINC_MKTS (Model 4). Moreover, the coefficients for INTERACT are larger than ones found in Table 4 where the overall measure of financial development was the dependent variable. This means that a conducive monetary 
environment helps remittances to exert a positive influence on banking services delivery and the smooth operation of financial markets beyond its substitutionary role. This finding suggests that remittances can aid financial intermediation provided the right monetary environment is built. Therefore, it is critical that developing countries that strive to improve financial intermediation anchor it on sound monetary fundamentals.

From Model 7 of Table 5, it is seen that remittances and monetary policy have a positive correlation with financial stability (FINC_STAB), but, it is only the coefficient of monetary policy which is significant. This means that financial stability in developing countries largely depends on monetary stability. The coefficient of INTERACT possesses a negative sign contrary to expectation and is marginally significant. The inability of monetary policy to interact with remittances to reduce financial instability is not entirely surprising. The empirical literature shows that remittances can lead to significant exchange rate appreciation (Acosta et al., 2009; Amuedo-Dorantes \& Pozo, 2004; Winters \& Martins, 2004) which can be a source of financial instability.

Remittance shows a negative association with business (BUS_ENV) and institutional (INST_ENV) environment but is only significant in terms of its effect on the business environment. This means that in countries with weak institutions and unfavourable business environment, remittances inflows increase to compensate households for losses and inconveniences they will incur as a result of the warped business systems and institutional environment. In terms of its effect on access (ACCESS) to formal credit, remittance shows a negative sign supporting the substitutionary role of remittances in credit markets. Again, the coefficient of INTERACT is positive and insignificant. This means that with the right monetary environment, banks and other financial institutions will be willing to give out loans from deposits that have been accumulated from remittances. Moreover, monetary freedom displays an affirmative and significant effect on access highlighting the role of monetary stability in boosting access to funds from the formal credit circuit.

Interest rate (MMIR) shows a negative relationship with all but one of the subcomponents of financial development and is significant for BANKS and FINC_ STAB, implying that high interest rates hurt almost all facets of the financial sector. This further suggests that a contractionary monetary policy should be applied with caution. Unbridled tightening of monetary policy can cause financial development to deteriorate. According to Bruno and Shin (2015) a contractionary monetary shock can cause cross-border banking capital flows to decline. 
Commenting briefly on the control variables, the measure of the legal environment (PTY_RIGHTS) shows results which are largely in line with La Porta et al. (1998). Its coefficient is positive in all the models (the only exception being FINC_STAB Model 7), but shows significance with financial markets and financial stability. Trade openness (TRADE_OPEN) is found to boost banking financial services and the business and institutional environment components of financial development. Financial openness (FINC_OPEN) is also found to significantly promote all the disaggregated components of financial development with the exception of FINC_STAB and BUS_ENV. Thus, overall, financial openness is good for financial development. This concurs with the extant literature and particularly with Chinn and Ito (2006) that with the right legal environment in place, financial openness accelerates financial development.

Savings is found to be important only for nonbank financial services. Lastly, labour freedom (LAB_FRE) shows a negative effect on financial intermediation services provided by banks. This finding is plausible because where labour is free to move around, the staff turnover ratio is high in the banking sector which may hamper the smooth operations of banks.

\section{CONCLUSION}

The study commenced the empirical inquiry by examining the independent effects of each of remittances and monetary conditions on financial development using instrumental variable based procedures. It reveals that favourable monetary conditions in remittance receiving countries promote financial development. Again, it establishes that remittances play the role of financial markets by reducing credit constraints in countries where the financial system is not developed enough to provide funding for entrepreneurs. Indeed, the main results showed that remittance does promote financial development but only when monetary freedom prevails. Otherwise, remittances act as substitutes to financial development.

Results obtained from a disaggregated analysis proved useful. The results reveal that when banking financial intermediaries and nonbank financial institutions and financial markets shirk their financial intermediation responsibilities, remittance inflows rise as a form of 'insurance cover' to cushion remittance recipients from the repercussions of dysfunctional financial systems. The insurance properties of remittances are further buttressed by the finding that in countries with weak institutions and unfavourable business environment, remittances inflows increase to compensate households for losses and inconveniences they will incur as a result of the substandard business systems and defective institutional environment. 
The findings are germane to economic policy formulation and implementation in developing countries. Monetary authorities have the opportunity to effectively utilise remittances to transform their financial systems by implementing monetary policies that ensure price stability while removing price distortions. Such policies should be non-inflationary in nature but not necessarily inflation targeting policy per se. Again, policies that reduce the burden of sending and receiving remittances should be pursued vigorously. Lastly, it is cautioned that, intemperate monetary contraction could hurt financial development.

In terms of future research opportunities, it is recommended that future studies should probe possible variations in the moderating influence of monetary policy in the link between remittances and financial development in advanced and developing economies using the comprehensive measures of financial development employed in this study.

\section{References}

Abdih, Y., Chami, R., Dagher, J. and Montiel, P. (2012). Remittances and institutions: are remittances a curse? World Development, 40(4), pp. 657-666.

Acosta, P.A., Lartey, E.K.K. and Mandelman, F.S. (2009). Remittances and the Dutch disease. Journal of International Economics, 79(1), pp.102-116.

Aggarwal, R., Demirgüç-Kunt A., and Pería, M.S.M. (2011). Do remittances promote financial development? Journal of Development Economics, 96(2), pp. 255-264.

Amidu, M. and Wolfe, S. (2013). The effect of banking market structure on the lending channel: evidence from emerging markets. Review of Financial Economics, pp. 22(4), 146-157.

Baltagi, B.H., Demetriades, P.O. and Law, S.H. (2009). Financial development and openness: Evidence from panel data. Journal of Development Economics, 89(2), pp. 285-296.

Bańbura, M., Giannone, D. and Reichlin, L. (2010). Large Bayesian vector auto regressions. Journal of Applied Econometrics, 25(1), pp. 71-92.

Bernanke, B., and Gertler, M. (1989). Agency costs, net worth, and business fluctuations. The American Economic Review, 79(1), pp. 14-31.

Bernanke, B.S., Gertler, M. and Gilchrist, S. (1996). The flight to quality and the financial accelerator. Review of Economics and Statistics, 78(1), pp. 1-15.

Bernanke, B.S. and Kuttner, K.N. (2005). What explains the stock market's reaction to Federal Reserve policy? The Journal of Finance, 6o(3), pp. 1221-1257. 
Billmeier, A. and Massa, I. (2009). What drives stock market development in emerging markets - institutions, remittances, or natural resources? Emerging Markets Review, 10(1), pp. 23-35.

Brown, R.P.C., Carmignani, F. and Fayad, G. (2013). Migrants' remittances and financial development: Macro - and micro-level evidence of a perverse relationship. The World Economy, 36(5), pp. 636-66o.

Cadet, R.L. (2009). A theory of linkage between monetary policy and banking failure in developing countries. Journal of Financial Economic Policy, 1(2), pp. 143-154.

Chowdhury, M.B. (2011). Remittances flow and financial development in Bangladesh. Economic Modelling, 28(6), pp. 2600-2608.

Cihak, M., Demirgüç-Kunt, A., Feyen, E. and Levine, R. (2012). Benchmarking financial systems around the world. Policy Research Working Paper (6175), World Bank.

Cooray, A. (2012). Migrant remittances, financial sector development and the government ownership of banks: Evidence from a group of non-OECD economies. Journal of International Financial Markets, Institutions and Money, 22(4), pp. 936-957.

De Graeve, F., Kick, T. and Koetter, M. (2008). Monetary policy and financial (in) stability: An integrated micro-macro approach. Journal of Financial Stability, 4(3), pp. 205-231.

Davidson, R. and MacKinnon, J.G. (1993). Estimation and inference in econometrics. New York: Oxford Univerity Press.

Demirgüç-Kunt, A., Córdova, E.L., Pería, M.S.M. and Woodruff, C. (2011). Remittances and banking sector breadth and depth: Evidence from Mexico. Journal of Development Economics, 95(2), pp. 229-241.

El-Sakka, M.I., and McNabb, R. (1999). The macroeconomic determinants of emigrant remittances. World Development, 27(8), pp. 1493-1502.

Elbourne, A. and de Haan, J. (2006). Financial structure and monetary policy transmission in transition countries. Journal of Comparative Economics, 34(1), pp. 1-23.

Ezeoha, A.E. (2013). Financial Determinants of international remittance flows to the sub-Saharan African region. International Migration, 51, pp. e84-e97.

Greene, W.H. (2003). Econometric Analysis (5th ed.). New Jersey: Prentice Hall.

Ginebri, S., Petrioli, G. and Sabani, L. (2001). Financial deepening, trade openness and growth: A multivariate cointegrated analysis of the complementary effects. Università di Roma La Sapienza. 
Giuliano, P. and Ruiz-Arranz, M. (2009). Remittances, financial development, and growth. Journal of Development Economics, 9o(1), pp. 144-152.

Gupta, S., Pattillo, C.A. and Wagh, S. (2009). Effect of remittances on poverty and financial development in sub-Saharan Africa. World Development, 37(1), pp. 104-115.

Hsueh, S.-J., Hu, Y.-H. and Tu, C.-H. (2013). Economic growth and financial development in Asian countries: A bootstrap panel Granger causality analysis. Economic Modelling, 32, pp. 294-301.

Issahaku, H., Abor, J.Y. and Harvey, S.K. (2017). Remittances, banks and stock markets: Panel evidence from developing countries. Research in International Business and Finance, 42(Supplement C), pp. 1413-1427.

Jedidia, K.B., Boujelbène, T. and Helali, K. (2014). Financial development and economic growth: New evidence from Tunisia. Journal of Policy Modeling, 36(5), pp. $883-898$.

Komal, R. and Abbas, F. (2015). Linking financial development, economic growth and energy consumption in Pakistan. Renewable and Sustainable Energy Reviews, 44, pp. 211-220.

Krause, S. and Rioja, F. (2006). Financial development and monetary policy efficiency. Department of Economics, Geargia State University.

Sobiech, I. (2019). Remittances, finance and growth: does financial development foster the impact of remittances on economic growth? World Development, 113, pp. 44-59.

Lee, C.-I. (2007). Does provision of public rental housing crowd out private housing investment? A panel VAR approach. Journal of Housing Economics, 16(1), pp. 1-20.

Levine, R. (2005). Finance and growth: Theory and evidence. Handbook of economic growth, 1, pp. 865-934.

Li, Y.D., İşcan, T.B. and Xu, K. (2010). The impact of monetary policy shocks on stock prices: Evidence from Canada and the United States. Journal of International Money and Finance, 29(5), pp. 876-896.

Mandelman, F.S. (2013). Monetary and exchange rate policy under remittance fluctuations. Journal of Development Economics, 102, pp. 128-147.

Minea, A. and Tapsoba, R. (2014). Does inflation targeting improve fiscal discipline? Journal of International Money and Finance, 40, pp. 185-203. 
Rajan, R.G. and Zingales, L. (2003). The great reversals: the politics of financial development in the twentieth century. Journal of Financial Economics, 69(1), pp. 5-50.

Singer, D.A. (2010). Migrant remittances and exchange rate regimes in the developing world. American Political Science Review, 104(02), pp. 307-323.

Stratan, A. and Chistruga, M. (2012). Economic consequences of remittances. Case of Moldova. Procedia Economics and Finance, 3, pp. 1191-1195.

Termos, A., Naufal, G. and Genc, I. (2013). Remittance outflows and inflation: The case of the GCC countries. Economics Letters, 120(1), pp. 45-47.

Vacaflores, D.E. (2012). Remittances, monetary policy, and partial sterilization. Southern Economic Journal, 79(2), pp. 367-387.

World Economic Forum (WEF). (2013). The Financial Development Report 2012. Geneva, Switzerland: The World Economic Forum.

\section{APPENDIX}

\section{Table A.1: Summary of measurements}

IFS: International Financial Statistics database of the IMF; WEF: World Economic Forum; WDI: World Development Indicators; HF: The Heritage Foundation; AC: Authors' Computation from various data sources.

\begin{tabular}{|l|l|l|l|l|}
\hline Variable & Description & Source & Mean & Std. Dev. \\
\hline FD_INDEX & $\begin{array}{l}\text { A composite measure of financial } \\
\text { development encompassing six } \\
\text { dimensions: institutional environment, } \\
\text { business environment, financial stability, } \\
\text { banking financial services, non-banking } \\
\text { financial services, financial markets, and } \\
\text { financial access. }\end{array}$ & WEF & 3.1434 & 0.4724 \\
\hline INST_ENV & $\begin{array}{l}\text { An index of institutional environment } \\
\text { dimension of financial development } \\
\text { embracing indicators of financial sector } \\
\text { liberalization, corporate governance, } \\
\text { legal and regulatory issues, and contract } \\
\text { enforcement. }\end{array}$ & WEF & 3.6754 & 0.6292 \\
\hline BUS_ENV & $\begin{array}{l}\text { Measures the business environment } \\
\text { aspect of financial development. Captures } \\
\text { indicators of human capital, taxes, } \\
\text { infrastructure, and costs of doing business. }\end{array}$ & $\begin{array}{l}\text { Measures the stability of the financial } \\
\text { system. Captures the risk of currency } \\
\text { crises, systemic banking crises, and } \\
\text { sovereign debt crises. }\end{array}$ & 3.8463 & 0.5915 \\
\hline FINC_STAB & WEF & 4.1537 & 0.7211 \\
\hline
\end{tabular}


Table 1. A Con't.

\begin{tabular}{|c|c|c|c|c|}
\hline Variable & Description & Source & Mean & Std. Dev. \\
\hline BANKS & $\begin{array}{l}\text { Measures the degree of banking sector } \\
\text { development. Encompasses measures } \\
\text { of banking sector size, efficiency, and } \\
\text { financial information disclosure. }\end{array}$ & WEF & 3.1129 & 0.7507 \\
\hline NONBANKS & $\begin{array}{l}\text { Measures the degree of advancement of } \\
\text { nonbank financial services. It includes } \\
\text { measures of initial public offering } \\
\text { and mergers and acquisition activity, } \\
\text { insurance, and securitisation. }\end{array}$ & WEF & 2.1031 & 0.8429 \\
\hline FINC_MKTS & $\begin{array}{l}\text { Measures the degree of advancement of } \\
\text { financial markets. Covers indicators of } \\
\text { foreign exchange and derivatives markets, } \\
\text { and equity and bond market development. }\end{array}$ & WEF & 1.8793 & 0.6148 \\
\hline ACCESS & $\begin{array}{l}\text { Measures financial access both retail and } \\
\text { commercial. }\end{array}$ & WEF & 3.1133 & 0.6783 \\
\hline REMIT & $\begin{array}{l}\text { Migrant remittances inflow as a ratio of } \\
\text { GDP. }\end{array}$ & WDI & 0.0307 & 0.0364 \\
\hline MON_FRE & $\begin{array}{l}\text { Measure of monetary policy effectiveness } \\
\text { (money freedom). It is a combined measure } \\
\text { of price stability and the degree of price } \\
\text { controls in the economy. }\end{array}$ & $\mathrm{HF}$ & 71.7933 & 7.0434 \\
\hline MMIR & $\begin{array}{l}\text { It is the money market interest rate. It is an } \\
\text { additional measure of monetary policy }\end{array}$ & IFS & 6.0512 & 3.4873 \\
\hline GS & Gross savings as a ratio of GDP. & WDI & 0.2601 & 0.1003 \\
\hline FINC_OPEN & $\begin{array}{l}\text { A proxy for financial openness, measured } \\
\text { by foreign direct investment as a ratio of } \\
\text { GDP. }\end{array}$ & WDI & $1.96 \mathrm{E}+08$ & $4 \cdot 72 \mathrm{E}+08$ \\
\hline TRADE_OPEN & $\begin{array}{l}\text { Total trade as a ratio of GDP; a proxy for } \\
\text { trade openness. }\end{array}$ & WDI & 0.7599 & 0.4127 \\
\hline PTY_RIGHTS & $\begin{array}{l}\text { Measures the degree of protection for } \\
\text { property rights. }\end{array}$ & WDI & $37 \cdot 7333$ & 14.1372 \\
\hline LAB_FRE & $\begin{array}{l}\text { Measures the degree of labour freedom } \\
\text { in a country. It captures minimum wage } \\
\text { regulations, regulations hindering layoffs, } \\
\text { and laws on hiring and hours of work. }\end{array}$ & $\mathrm{HF}$ & 58.8893 & $13 \cdot 7154$ \\
\hline INTERACT & $\begin{array}{l}\text { Interaction between remittances and } \\
\text { monetary policy effectiveness (money } \\
\text { freedom). }\end{array}$ & $\mathrm{AC}$ & & \\
\hline GROWTH & Annual GDP growth. & WDI & 4.2687 & 3.8749 \\
\hline
\end{tabular}

